\title{
"Validation of a Cyberbullying Questionnaire as a Screening Tool for Other Forms of Intimate-Partner Violence Towards Young Women"
}

Lucía Hernández-García ( $\square$ luciahhgb@gmail.com)

General Directorate of Public Health, Madrid, Spain https://orcid.org/0000-0002-7763-6707

Myrian Pichiule Castañeda

General Directorate of Public Health of Madrid, Epidemiology Department

Luisa Lasheras Lozano

General Directorate of Public Health of Madrid, Health Promotion Department

Marisa Pires Alcaide

General Directorate of Public Health of Madrid, Department of Health Promotion

María Ordobás Gavín

General Directorate of Public Health, Epidemiology Department

Ana Gandarillas Grande

General Directorate of Public Health of Madrid, Epidemiology Department

\section{Research article}

Keywords: Cyber-dating abuse, gender-based violence, intimate-partner violence, health surveys, validation study, mass screening, young adult

Posted Date: October 5th, 2020

DOI: https://doi.org/10.21203/rs.3.rs-72136/v1

License: (c) (1) This work is licensed under a Creative Commons Attribution 4.0 International License. Read Full License 


\section{Abstract}

Fundamentals:

The use of electronic media is widespread among young people and is a potential tool for the perpetration of intimate-partner violence (IPV) towards women. The aim of this study is to validate two questions focused on harassment and control by electronic tools (HCE-2) as a screening tool for the detection of IPV in young women.

\section{Methodology:}

The data source was the third Community of Madrid IPV survey in 2014. The screening tool consisted of two questions with five possible answers prepared by a group of experts. The gold-standard definition of IPV was that of a questionnaire of 26 questions. The validity indices (with $95 \%$ confidence intervals) were compared between two age groups: 18-24 and 25-29 years.

\section{Results:}

The response rate was $68.7 \%$, and 477 surveys were analyzed. The prevalence of IPV was $10.7 \%$ (95\% Cl: 8.2-13.8). HCE-2 was positive in 5.9\% (95\% Cl: 4.18.4). The overall efficiency of the test was $93.5 \%$ (95\% Cl: $91.1-96.7)$, sensitivity $47.1 \%$ (95\% Cl: $33.7-60.8)$, specificity $99.1 \%$ (95\% Cl: $97.5-99.6)$, and positive predictive value $85.7 \%$ (95\% Cl: $67.1-94.6)$. The best validity indices of the questionnaire were observed in women aged 18 to 24 years: overall efficiency of the test 95.1\% (95\% Cl: 92.6-97.7), sensitivity 62.5\% (95\% Cl: 44.5-77.6), specificity 99.6\% (95\% Cl: 97.0-99.9), and positive predictive value 95.2\% (95\% Cl: 71.799.4).

\section{Conclusions:}

The existing need to improve the detection of IPV in young women and the good validity indices observed here justify the recommendation of the HCE-2 questionnaire as a screening tool in young women.

\section{Introduction}

Gender-based violence is a social and health problem widely described in the literature and is recognized as a violation of basic human rights, with psychological and physical consequences for both the victim and their environment ${ }^{1,2}$. Despite the social changes that have occurred in recent decades, this type of violence is still present in all stages of life, with intimate-partner violence (IPV) being the most common form and young women being the most frequently affected demographic group. In Spain, $26.4 \%$ of women have suffered psychological violence from their partner or ex-partner over the course of their lives, and $9.5 \%$ have experienced it in the last year, while in women aged 16 to 24 years, these percentages are $38.3 \%$ and $21.1 \%$, respectively ${ }^{3}$. In addition to suffering violence more often, young women seem to be more vulnerable to its consequences ${ }^{4}$.

There are many ways this violence is perpetrated, classically grouped into psychological, physical, and sexual violence. In recent years, electronic media have gained prominence in interpersonal communications, especially in youths, constituting a new possible mechanism for perpetrating violence ${ }^{5}$. The different types of violence are not exclusive; they often coexist, and a correlation has been observed with cyberbullying in dating partners ${ }^{6-8}$.

The identification of cases of IPV is fundamental both for surveillance and for an early and adequate approach that minimizes its consequences and facilitates access to specific resources. The Spanish Organic Law $1 / 2004^{9}$ adopts measures to optimize the early detection of gender-based violence in a healthcare setting ${ }^{10}$, however the screening tools studied have poorer validity indices in the young population ${ }^{4,11}$, which reflects the need to adapt screening to different stages of life. The Ministry of Health considers it necessary to develop tools for measuring cyber-dating abuse as a form of IPV in young people ${ }^{12}$, on this line, one of the measures included in the national strategy for eradicating violence against women is to study cyberbullying as a new form of gender violence among young people and young couples ${ }^{13}$.

The objective of this study is to validate two questions on the perceptions of harassment and control by electronic tools (HCE-2) as a population screening tool for IPV in youths.

\section{Material And Methods}

This was a validation study of a screening questionnaire on IPV towards women based on a cross-sectional population-based study.

\section{Study population and data collection:}

The source of information was the third survey to study the magnitude, trend, and health impact of IPV towards women in the Community of Madrid, $2014{ }^{14}$. The data were collected between December 2013 and February 2014. The sampling frame was the Individual Health Card database, which allows access to the health system to almost all of the population. The sample was stratified via proportional affiliation to the strata determined by the crossing of three geographical areas, age groups (four groups) and country of birth (born in Spain or outside Spain). The information was collected through a computerassisted telephone interview.

This study included women in the sample aged 18 to 29 who reported having had a partner or contact with a former partner of the opposite gender in the last year. 
Study variables:

- Definition of IPV: Cases of violence were defined by a questionnaire of 26 questions selected from the ENVEFF questionnaire (Enquête national sur le violences envers les femmes en France) for the detection of psychological and sexual violence and the CTS-1 (Conflict Tactics Scales) questionnaire for the detection of physical violence. These questionnaires were used as references in this study. The Spanish version was validated in 2004 in women in the Community of Madrid through an in-depth interview conducted by two trained psychologists. They found that this questionnaire showed a sensitivity for the detection of IPV of $80.4 \%(79.3-81.6)$ and a specificity of $90.0 \%(88.9-91.0)^{15}$. Only one relationship (the most recent) was considered per participant in the study.

- Definition of cyberbullying: To explore the perception of harassment and control by electronic tools by the couple, the HCE-2 questionnaire was designed. It consisted of two questions developed ad hoc by a group of experts, shown in Table 1, with five possible responses on a Likert scale. Cyberbullying was considered to be present in women who scored greater than or equal to 1, with a positive response of "sometimes", "often" or "constantly/always/systematically" to at least one of the two questions.

- Sociodemographic variables: Age was stratified in two groups (18-24 and 25-29 years). The country of birth of the woman and her partner was either Spain or outside of Spain. Maximum level of schooling attained, employment status, type of relationship (partner or ex-partner), living with the partner or not, and whether or not they had children were also surveyed.

Statistical analysis: The population prevalence of IPV in the year before the survey, the prevalence of cyberbullying, and their $95 \%$ confidence intervals (95\% Cls) were estimated. Several validity indices of the cyberbullying questionnaire for the detection of IPV were calculated: sensitivity, specificity, positive predictive value (PPV), negative predictive value (NPV), positive odds ratio (POR), and negative (NOR), the overall efficiency of the test, and their 95\% Cls. For the comparison of qualitative variables, the chi-squared test or Fisher's exact test was used as more than $20 \%$ of the expected values were less than $5{ }^{16}$. For all tests, statistical significance was accepted at the 0.05 level. The analysis was performed with the statistical program STATA version 15 (StataCorp, College Station, Texas, USA 2017).

\section{Results}

The overall response rate of the survey was $60.5 \%$ (women $18-70$ years), with the highest response rate among women $18-24$ years (68.7\%) ${ }^{2}$. The HCE-2 questionnaire was open to all women, without a filtering question, and a response rate of $100 \%$ was obtained.

The sociodemographic characteristics of the young women according to age group are presented in Table 2. Significant differences were found between women aged 18-24 and 25-29 years in schooling level, employment status, and whether they had children. Among the youngest age group, most were students (34.7\%), while in the group aged 25 to 29 years, the majority of women were employed (65.1\%).

Regarding intimate relationships, in most cases the relationship with the current partner (82.8\%) was explored, and in the rest with a former partner. The women aged 18-24 years lived with their partners less often than older women (19.4\% vs. 63.2\%), and young women had children less often than older women (10.5\% vs. $25.8 \%)$.

The distribution of the responses to the harassment and control questions and their prevalence are shown in Table 3. In the sample, 51 cases of IPV were detected (prevalence 10.7\%). The prevalence was higher among the youngest age group (11.9\%; 95\% Cl: 8.6-16.4) than the older (9.1\%; 95\% Cl: 5.-13.8), but this was not statistically significant.

The HCE-2 questionnaire was positive in $5.9 \%$ of women ( $95 \% \mathrm{Cl}: 4.1-8.4)$. When examining the two questions independently, there was a higher rate of positive responses to the control question (5.5\%) than to the harassment question (3.4\%). Among those who reported harassment by their partner, most responded "Sometimes" $(2.1 \%)$, followed by "Constantly or always" $(0.8 \%)$. Women who reported being controlled by their partners also responded more frequently "Sometimes" (3.6\%) followed in this case by "Often" (1.0\%).

The prevalence of cyberbullying was twice as high in the younger women (18-24 years) as in women aged $25-29$ years (7.8\% vs. $3.3 \%$ ). This difference was most notable on the harassment question, with positive response rate of $5.2 \%$ in the younger group and $1.0 \%$ in the older group.

Female victims of cyberbullying were also classified as victims of IPV in $85.7 \%$ of cases. This percentage was higher in the group aged $18-24$ years (95.2\%); of these, only one woman out of the 28 who scored positive for cyberbullying was not classified as a victim of IPV.

The validity indices for the sample as a whole and by age group are shown in Table 4. Among women aged 18-24 years, the sensitivity, or probability of correctly classifying a victim of IPV through the questionnaire, was $62.5 \%$ (95\% Cl: 44.5-77.6). The specificity, or probability of correctly classifying a non-IPV woman, was $99.6 \%$ (95\% Cl: 97.0-99.9). The questionnaire presented a PPV of 95.2\% (95\% Cl: 71.7-99.4) and a NPV of 95.1\% (95\% Cl: 91.6-97.2). There was 147.5 times higher probability (POR) of presenting a positive result in the questionnaire among women who suffered from IPV than among those who did not suffer violence. The overall efficiency of the test, or probability of correctly classifying a woman as a victim of IPV or not, was $95.1 \%$ (95\% Cl: $92.6-97.7)$.

Among women aged 25-29 years, poor validity indices were observed. The sensitivity and specificity were $21.1 \%$ (95\% Cl: 7.9-45.5) and 98.4\% (95\% Cl: 95.299.5), respectively. A PPV of 57.1\% (95\% Cl: 20.8-87.1) and a NPV of 92.6\% (95\% Cl: $88.0-95.5)$ were observed. The POR was 13.3 , and the overall efficiency of the test was $91.4 \%(95 \% \mathrm{Cl}: 87.6-95.2)$.

\section{Discussion}


This study explores the validity of a two-question questionnaire, HCE-2, which surveys the perception of harassment and control by electronic tools, as a screening tool for the detection of cases of IPV in young women. In the analysis, good validity indices were obtained, and these indices were better in the group of women aged 18-24 years, in which an overall test efficiency of $95.1 \%$ and a PPV of $95.2 \%$ were observed.

Cyberbullying within relationships has been described as a type of digital practice in which the aggressor exercises domination over the victim through harassing strategies that affect her privacy and intimacy ${ }^{12}$. This work addresses cyberbullying from a gender perspective. Most of the studies reviewed analyze cyberbullying in the context of violence in general, aimed at the detecting both victims and perpetrators of both genders. This fact might make it difficult to compare our results with others.

The use of electronic tools to perpetrate different acts of violence is relatively new. Whether electronic media incite violence or are a mere new avenue for it has been discussed in previous publications, but there are still discrepancies. Electronic media have certain characteristics that differentiate them from other forms of violence: their immediacy, their lack of geographical boundaries, and the possibility of communicating online ${ }^{7}$. Electronic media are also heterogeneously distributed, with the young population using them the most ${ }^{5}$. INE data from 2012 (the latest before this study) indicate that $95.3 \%$ of young women are frequent users of electronic media ${ }^{17}$.

Discrepancies are also observed in terms of terminology and classification. Some authors consider harassment and control by electronic tools an independent type of IPV, while others consider it a subtype of psychological violence ${ }^{18}$. Although there is no agreement on this matter, there appears to be an association between harassment and control by electronic tools in the couple and IPV towards women, called offline IPV. A study conducted in the United States in university students between 18 and 25 years of age observed a significant correlation between cases of cyberbullying within the couple and psychological, physical, and sexual violence 6 . Specifically, $95 \%$ of the participants who suffered psychological violence from their partner also suffered it by electronic tools, and conversely, those who suffered harassment by electronic tools were 28 times as likely to report psychological violence from a partner as those who did not suffer harassment. These figures support the results obtained in our study, where $95.2 \%$ of women aged 18 to 24 years who suffered cyberbullying also met the criteria of IPV. In other studies, our results are in line with others ${ }^{8,19-21}$ showing a strong association between harassment and control by electronic tools and psychological partner violence.

Violence by electronic media could hinder self-perception of violence, since among young people, control and harassment are often confused with attention and caring. This perception is fostered by the idea of romantic love ${ }^{5}$, and in turn, the normalization of these behaviors favors the onset of violence ${ }^{19}$. However, other studies have shown that the negative consequences of IPV are present even when women are not perceived as victims of IPV22.

The questions developed for our study have obtained good validity indices for the detection of IPV, especially in the age group of 18-24 years. Regarding scoring for the two questions, the response "rarely" was initially considered a positive score, but after observing a decrease in the overall efficiency of the questionnaire, it was given the same scoring as "never". Recently, the short version of the Woman Abuse Screening Tool (WAST) has been validated as an IPV screening tool, in which, despite obtaining very good results, the need for improvement in detection in young populations is expressed ${ }^{11}$. The screening test validated in this study presents better validity indices (overall test efficiency, specificity, PPV, and POR) than WAST when applied to women aged 18 to 29 years. On the other hand, this test presents slightly lower sensitivity and NPV, although both values are considerably better in the group of younger women (18-24 years). The brevity of this test gives it an advantage over other tests geared towards young people $e^{4,19}$.

Among the limitations of this study is the nonresponse bias because it could be expected that the prevalence of IPV among women who did not want to participate in the interview would differ from the prevalence in the women who did respond. There may also be selection bias, as we included only women with an individual health card, though this would be minimal, since it is issued to almost $100 \%$ of the population. Added to these limitations is that we took as the gold standard a definition based on self-reported information, instead of a specialized clinical interview, and we collected information only on the most recent partner of each woman in the case that there was more than one partner in the year before the interview. The biggest strengths of the test are its brevity and simplicity, which facilitate its rapid implementation and positive acceptance by women (response rate of $100 \%$ in our sample). Since 2017 , the two questions analyzed have been included in the Noncommunicable Disease Risk-Factor Surveillance System that annually monitors behavior in young people (SIVFRENTJ) in the Community of Madrid.

In conclusion, due to the need to improve the detection of IPV in young women and the good results of this exploratory study, it is recommended to consider cyberbullying to screen for other forms of violence in women between 18 and 24 years of age. It will be necessary to carry out more studies to ensure that the results obtained here are reliable.

\section{Declarations}

\section{Ethics approval:}

The study protocol of the survey was evaluated and approved by the Ethics Committee for Clinical Research at La Princesa University Hospital in Madrid

\section{Availability of data and materials:}

The datasets during and/or analysed during the current study available from the corresponding author on reasonable request and with permission from the Directorate General for Public Health.

Competing interests: 
The authors declare no conflicts of interest.

\section{Funding:}

The survey was conducted with funds from the General Directorate of Public Health. Funding from the Foundation for Research and Biosanitary Innovation of Primary Care of the Madrid Health Service was provided for translation and publication expenses.

\section{Authors' contributions:}

All the authors have participated in the conception, design, or interpretation of the results. The analysis and writing of the article were mainly carried out by L. Hernández and M. Pichiule. The work was coordinated by A. Gandarillas. All authors have critically reviewed the article, made contributions, and approved the final version for publication.

\section{Acknowledgments:}

To Dr. Vicente Pastor y Aldeguer for his comments on the preliminary documents that gave rise to this manuscript; to all the professionals who participated in the design of the survey; and to all the women who responded to the third survey.

\section{References}

1. Sonego M, Pichiule M, Gandarillas A, Polo C, Ordobás M. Mental health in girls and boys exposed to intimate partner violence. Public Health. 2018;164:26-9. doi:10.1016/j.puhe.2018.07.003.

2. Pichiule Castaneda M, Gandarillas Grande AM, Diez-Ganan L, Sonego M, Ordobas Gavin MA. [Young people dating violence surveillance in Madrid, Spain]. Rev Esp Salud Publica. 2014;88(5):639-52. doi:10.4321/S1135-57272014000500008.

3. Macroencuesta de Violencia Contra La Mujer 2015.; 2015. http://www.violenciagenero.igualdad.mpr.gob.es/violenciaEnCifras/estudios/colecciones/pdf/Libro_22_Macroencuesta2015.pdf. Accessed November 22,2019

4. García-Carpintero M, Rodríguez-Santero J, Porcel-Gálvez AM. Diseño y validación de la escala para la detección de violencia en el noviazgo en jóvenes en la Universidad de Sevilla. Gac Sanit. 2018;32(2):121-8. doi:10.1016/j.gaceta.2017.09.006.

5. Flach RMD, Deslandes SF. Cyber dating abuse in affective and sexual relationships: a literature review. Cad Saude Publica. 2017;33(7):e00138516. doi:10.15090/0102-311X00138516.

6. Marganski A, Melander L. Intimate Partner Violence Victimization in the Cyber and Real World: Examining the Extent of Cyber Aggression Experiences and Its Association With In-Person Dating Violence. J Interpers Violence. 2018;33(7):1071-95. doi:10.1177/0886260515614283.

7. Borrajo E, Gámez-Guadix M, Calvete E. Justification beliefs of violence, myths about love and cyber dating abuse. Psicothema. 2015;27(4):327-33. doi:10.7334/psicothema2015.59.

8. Hinduja S, Patchin JW. Electronic Dating Violence A Brief Guide for Educators and Parents.; 2011. https://cyberbullying.org/electronic_dating_violence_fact_sheet.pdf. Accessed November 17, 2019.

9. Ley Orgánica 1/2004, de 28 de Diciembre, de Medidas de Protección Integral Contra La Violencia de Género.; 2004. https://www.boe.es/eli/es/lo/2004/12/28/1/con.

10. Del Estado J. Ley Orgánica 1/2004. https://www.boe.es/boe/dias/2004/12/29/pdfs/A42166-42197.pdf. Accessed November 22, 2019.

11. Pichiule Castañeda M, Gandarillas Grande A, Pires Alcaide M, Lasheras Lozano L, Ordobás Gavín M. Validación de la versión corta del Woman Abuse Screening Tool (WAST) en población general. Gac Sanit. June 2019. doi:10.1016/j.gaceta.2019.04.006.

12. Torres C, Robles JM, De Marco S El Ciberacoso Como Forma de Ejercer La Violencia de Género En La Juventud: Un Riesgo En La Sociedad de La Información y Del Conocimiento. Delegación Del Gobierno Para La Violencia de Género; Ministerio de Sanidad, Servicios Sociales e lgualdad. Delegación del Gobierno para la Violencia de Género; 2014.

http://www.violenciagenero.igualdad.mpr.gob.es/violenciaEnCifras/estudios/colecciones/pdf/Libro_18_Ciberacoso.pdf.

13. Estrategia Nacional Para La Erradicación de La Violencia Contra La Mujer (2013-2016). Madrid; 2013. http://www.publicacionesoficiales.boe.es. Accessed January 8, 2020.

14. Pichiule M, Gandarillas A, Ordobás M, Sonego M, Zorrilla B, Pires M. Violencia de Pareja Hacia Las Mujeres: $3^{\circ}$ Encuesta Para El Estudio de La Magnitud, Tendencia e Impacto En Salud En La Comunidad de Madrid, 2014. Consejería de Sanidad. Dirección General de Atención Primaria. Documento Técnico de Salud Pública No138. Madrid; 2014. http://www.madrid.org/cs/Satellite?blobcol=urldata\&blobheader=application\%2Fpdf\&blobheadername1=Contentdisposition\&blobheadername2=cadena\&blobheadervalue1=filename\%3DVPM+19112014+definitivo+_2_.pdf\&blobheadervalue2=language\%3Des\%26site

15. Zorrilla B, Morant C, Polo C. Validación de un cuestionario para la violencia de pareja hacia las mujeres. Gac Sanit. 2005;19(1):53.

16. Kirkwood BR, Sterne JAC. Essential Medical Statistics.; 2003.

17. Instituto Nacional de Estadística. Encuesta sobre equipamiento y Uso de Tecnologías de Información y Comunicación de los Hogares. 2012. https://www.ine.es/dyngs/INEbase/es/categoria.htm?c=Estadistica_P\&cid=1254735576692. Accessed November 22, 2019.

18. Peskin MF, Markham CM, Shegog R, et al. Prevalence and Correlates of the Perpetration of Cyber Dating Abuse among Early Adolescents. J Youth Adolesc. 2017;46(2):358-75. doi:10.1007/s10964-016-0568-1. 
19. Borrajo E, Gámez-Guadix M, Pereda N, Calvete E. The development and validation of the cyber dating abuse questionnaire among young couples. Comput Human Behav. 2015;48:358-65. doi:10.1016/j.chb.2015.01.063.

20. Cutbush S, Williams J, Miller S, Gibbs DC-SM. Electronic dating aggression among middle school students: Demographic correlates and associations with other types of violence. 2012.

21. Zweig JM, Dank M, Yahner J, Lachman P. The rate of cyber dating abuse among teens and how it relates to other forms of teen dating violence. J Youth Adolesc. 2013;42(7):1063-77. doi:10.1007/s10964-013-9922-8.

22. Sonego M, Gandarillas A, Zorrilla B, et al. Unperceived intimate partner violence and women's health. Gac Sanit. 2013;27(5):440-6. doi:10.1016/j.gaceta.2012.11.009.

\section{Tables}

Table 1: Questionnaire on perceived harassment and control by electronic tools and scoring (HCE-2) (English version)

\section{Scoring of the harassment and control questionnaire by electronic tools}

Question 1. Have you felt harassed/overwhelmed by text messages or emails that he sends/has sent you?

$\begin{array}{lllcc}\text { Never } & \text { Rarely } & \text { Sometimes } & \text { Often } & \text { Constantly/always/systematically } \\ 0 & 0 & 1 & 1 & 1\end{array}$

(1)

Question 2. Have you felt overwhelmed because he controlled calls or messages on your cell phone or email?

$\begin{array}{lllcc}\text { Never } & \text { Rarely } & \text { Sometimes } & \text { Often } & \text { Constantly/always/systematically } \\ 0 & 0 & 1 & 1 & 1\end{array}$

Positive case: 1 or 2 points in total

Cuestionario de percepción de acoso y control a través de medios electrónicos y forma de puntuación (ACE-2) (Spanish versión)

Puntuación del cuestionario de acoso y control a través de medios electrónicos

Pregunta 1. ¿Se ha sentido acosada/ agobiada a través de mensajes de móvil o de correos electrónicos que él le envía/ enviaba?

$\begin{array}{lll}\text { Nunca } \quad \text { Rara vez Algunas veces } \quad \text { Muchas veces } & \text { Constantemente/ siempre/ } \\ \text { sistemáticamente } & \text { Alg }\end{array}$

0

1

1

Pregunta 2. ¿Se ha sentido agobiada debido a que le controlaba las llamadas o mensajes del móvil o su correo electrónico?

Nunca Rara vez Algunas veces Muchas veces Constantemente/ siempre/

$\begin{array}{lllll}0 & 0 & 1 & 1 & 1\end{array}$

Caso positivo: 1 o 2 puntos en total 


\begin{tabular}{|c|c|c|c|c|c|c|c|}
\hline & All $(n=477)$ & & $18-24$ years & $n=268)$ & $25-29$ years & $n=209)$ & \\
\hline Variable & Frequency & Percentage (\%) & Frequency & Percentage (\%) & Frequency & Percentage (\%) & p-value \\
\hline Schooling level & & & & & & & $<0.001$ \\
\hline High & 140 & 29.4 & 57 & 21.3 & 83 & 39.7 & \\
\hline Medium & 276 & 57.9 & 178 & 66.4 & 98 & 46.9 & \\
\hline Low & 58 & 12.2 & 32 & 11.9 & 26 & 12.4 & \\
\hline $\mathrm{NC}$ & 3 & 0.6 & 1 & 0.4 & 2 & 1.0 & \\
\hline Place of birth & & & & & & & 0.073 \\
\hline Spain & 357 & 74.8 & 209 & 78.0 & 148 & 70.8 & \\
\hline Other & 120 & 25.2 & 59 & 22.0 & 61 & 29.2 & \\
\hline Employment situation & & & & & & & $<0.001$ \\
\hline Paid work & 233 & 48.9 & 97 & 36.2 & 136 & 65.1 & \\
\hline Unemployed & 110 & 23.1 & 66 & 24.6 & 44 & 21.1 & \\
\hline Student & 102 & 21.4 & 93 & 34.7 & 9 & 4.3 & \\
\hline Housewife & 32 & 6.7 & 12 & 4.5 & 20 & 9.6 & \\
\hline Type of relationship & & & & & & & 0.052 \\
\hline Current partner & 395 & 82.8 & 214 & 79.9 & 181 & 86.6 & \\
\hline Ex-partner & 82 & 17.2 & 54 & 20.2 & 28 & 13.4 & \\
\hline Living together & & & & & & & $<0.001$ \\
\hline Yes & 184 & 38.6 & 52 & 19.4 & 132 & 63.2 & \\
\hline No & 293 & 61.4 & 216 & 80.6 & 77 & 36.8 & \\
\hline Children & & & & & & & $<0.001$ \\
\hline Yes & 82 & 17.2 & 28 & 10.5 & 54 & 25.8 & \\
\hline No & 395 & 82.8 & 240 & 89.6 & 155 & 74.2 & \\
\hline Country of partner/ex-partner & & & & & & & 0.508 \\
\hline Spain & 361 & 75.7 & 206 & 76.9 & 155 & 74.2 & \\
\hline Other & 115 & 24.1 & 61 & 22.8 & 54 & 25.8 & \\
\hline
\end{tabular}


Table 3: Distribution of responses to the questionnaire on harassment and control by electronic tools

\begin{tabular}{|c|c|c|c|c|c|c|c|c|c|}
\hline \multirow[b]{3}{*}{ Intimate-partner violence towards women } & \multicolumn{3}{|c|}{ All $(n=477)$} & \multicolumn{3}{|c|}{$\begin{array}{l}18-24 \text { years } \\
(n=268)\end{array}$} & \multicolumn{3}{|c|}{$\begin{array}{l}25-29 \text { years } \\
(n=209)\end{array}$} \\
\hline & \multirow{2}{*}{$\begin{array}{c}\% \\
10.7\end{array}$} & \multicolumn{2}{|c|}{$95 \% \mathrm{Cl}$} & \multirow{2}{*}{$\begin{array}{c}\% \\
11.9\end{array}$} & \multicolumn{2}{|c|}{$95 \% \mathrm{Cl}$} & \multirow{2}{*}{$\begin{array}{c}\% \\
9.1\end{array}$} & \multicolumn{2}{|c|}{$95 \% \mathrm{Cl}$} \\
\hline & & 8.2 & 13.8 & & 8.6 & 16.4 & & 5.9 & 13.8 \\
\hline Harassment and/or control & 5.9 & 4.1 & 8.4 & 7.8 & 5.2 & 11.7 & 3.3 & 1.6 & 6.9 \\
\hline \multicolumn{10}{|l|}{ Question 1. Harassment } \\
\hline $\begin{array}{l}\text { Have you felt harassed/overwhelmed by text messages or emails that he } \\
\text { sends/has sent you? }\end{array}$ & $\%$ & \multicolumn{2}{|c|}{$95 \% \mathrm{Cl}$} & $\%$ & \multicolumn{2}{|c|}{$95 \% \mathrm{Cl}$} & $\%$ & \multicolumn{2}{|c|}{$95 \% \mathrm{Cl}$} \\
\hline Never & 94.8 & 92.3 & 96.4 & 92.5 & 88.7 & 95.1 & 97.6 & 94.3 & 99.0 \\
\hline Rarely & 1.9 & 1.0 & 3.6 & 2.2 & 1.0 & 4.9 & 1.4 & 0.5 & 4.4 \\
\hline Sometimes & 2.1 & 1.1 & 3.9 & 3.0 & 1.5 & 5.9 & 1.0 & 0.2 & 3.8 \\
\hline Often & 0.4 & 0.1 & 1.7 & 0.7 & 0.2 & 3.0 & 0.0 & - & \\
\hline Constantly/always & 0.8 & 0.3 & 2.2 & 1.5 & 0.6 & 3.9 & 0.0 & - & \\
\hline Never/rarely & 96.6 & 94.6 & 97.9 & 94.8 & 91.3 & 96.9 & 99.0 & 96.2 & 99.8 \\
\hline Sometimes/often/constantly/always & 3.4 & 2.1 & 5.4 & 5.2 & 3.1 & 8.6 & 1.0 & 0.2 & 3.8 \\
\hline \multicolumn{10}{|l|}{ Question 2. Control } \\
\hline $\begin{array}{l}\text { Have you felt overwhelmed because he controlled calls or messages on your } \\
\text { cell phone or email? }\end{array}$ & $\%$ & \multicolumn{2}{|c|}{$95 \% \mathrm{Cl}$} & $\%$ & \multicolumn{2}{|c|}{$95 \% \mathrm{Cl}$} & $\%$ & \multicolumn{2}{|c|}{$95 \% \mathrm{Cl}$} \\
\hline Never & 91.6 & 88.8 & 93.8 & 88.4 & 84.0 & 91.8 & 95.7 & 91.9 & 97.8 \\
\hline Rarely & 2.9 & 1.7 & 4.9 & 4.1 & 2.3 & 7.3 & 1.4 & 0.5 & 4.4 \\
\hline Sometimes & 3.6 & 2.2 & 5.7 & 4.1 & 2.3 & 7.3 & 2.9 & 1.3 & 6.3 \\
\hline Often & 1.0 & 0.4 & 2.5 & 1.9 & 0.8 & 4.4 & 0.0 & - & \\
\hline Constantly/always & 0.8 & 0.3 & 2.2 & 1.5 & 0.6 & 3.9 & 1.0 & - & \\
\hline Never/rarely & 94.5 & 92.1 & 96.3 & 92.5 & 88.7 & 95.1 & 97.1 & 93.7 & 98.7 \\
\hline Sometimes/often/constantly/always & 5.5 & 3.7 & 7.9 & 7.5 & 4.9 & 11.3 & 2.9 & 1.3 & 6.3 \\
\hline
\end{tabular}

\begin{tabular}{|l|cccccc|}
\hline \multicolumn{2}{|l|}{ Table 4: Validity indices of the questionnaire on harassment and control by electronic tools in the detection of offline IPV } \\
\hline \\
\hline
\end{tabular}

